\title{
Museum education in semi-peripheries: social, cultural and economic aspects of the globalisation of Polish and Slovak heritage institutions ${ }^{1}$
}

\author{
Dominik Porczyński, Lenka Vargová
}

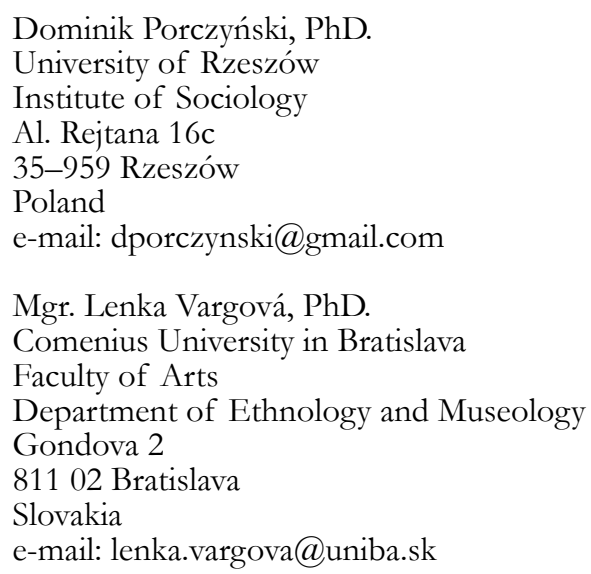

Muzeológia a kultúrne dedičstvo, 2020, 8:2:31-54

DOI: $10.46284 / \mathrm{mkd} .2020 .8 .2 .3$

\begin{abstract}
Museum education in semi-peripheries: social, cultural and economic aspects of the globalisation of Polish and Slovak heritage institutions

The paper examines the problem of change in Central-Eastern European museum education in the globalising world. The main objective is to answer the question of whether museums located in peripheral regions of semi-peripheral states introduce patterns developed in global core-states or maintain the approach invented during the former political period. Its main assumption is that globalisation is a discursive process engaging global, national and local cultural elements, leading to reshaping of local patterns.

The paper is based on 14 in-depth interviews conducted with curators working at local museums of the Subcarpathian and Košice regions, supported by four interviews carried out with museum workers of national museums in Warsaw and Bratislava.
\end{abstract}

Keywords: Globalisation, Museum Education, Peripherality, Poland, Slovakia

\section{Museums and globalisation}

The aim of this paper is to determine whether museums located in peripheral regions of Poland and Slovakia underwent changes in the field of museum education after the fall of communism. We would also like to answer the question of whether the ongoing process of globalisation and incorporation of both countries into the structures of the European Union and museum networks influences local museum pedagogy practices.

${ }^{1}$ This paper is the outcome of the research project Rola muzeów w konstruowaniu tożsamości lokalnych $w$ Polsce i na Stowacii (The role of museums in constructing local identities in Poland and Slovakia) IA-11/2017/508, financially supported by the fund for carrying out scientific research and related tasks supporting the development of young scholars and doctoral studies participants at the University of Rzeszów Department of Sociology and History. 
Studying local museums in the globalising world raises some doubts about the legitimacy of research into cultural institutions that treats them as independent entities separated from a broader context. The world of closed communities began to cease with the advent of modernity. ${ }^{2}$ Treating organisations and communities as independent-as is done in more traditional ethnography or in case studies - is often an important strategy for defining a field of study. Yet in the case of museums, such focus might decrease the quality of collected data. Museums as the subject of social sciences should be studied with their historical background, ${ }^{3}$ which once again moves us towards anthropological—and thus more locally oriented-methodology. The historically changing model of the institution has more to do with global processes, however. The study of museums deals with local and global patterns simultaneously. The institution reinterprets the product of the nation or region within the universalised categories of the globalisation process (psychotherapy, folklore, theatre, art). ${ }^{4}$ Even if certain artefacts are treated as "global" heritage, they are interpreted locally. ${ }^{5}$ On the one hand, local museums deal with geographically and culturally limited phenomena. Looking from the perspective of the state, or states united by a political system, the museology of the former communist countries developed in a certain isolation and applied a somewhat different, ideologically-based approach ${ }^{6}$ from its Western counterpart. On the other hand, certain patterns in museum development and functioning bring the local, regional, national, and global together. Some authors, in fact, treat these institutions as factors of globalisation. Martin Prösler suggests that museums have not just followed world development, but their attachment to processes of colonialism and imperialism has helped the global spread of certain ideas such as nation and national identity, and has shaped the contemporary world. ${ }^{7}$

Globalisation, according to Anthony Giddens, is an intensification of worldwide social relations linking distant localities in such a way that local happenings are shaped by events occurring many thousands of miles away and vice versa. ${ }^{8}$ It is a multidimensional process ${ }^{9}$ and certain aspects might proceed individually. The source of the concept of globalisation lies in the spheres of economics and finance. ${ }^{10}$ According to Immanuel Wallerstein there is a certain setup of states — core, semi-peripheral and peripheral — and a one-directional transfer of patterns from the core to the peripheries, leading to an eventual subordination of the latter to the former. ${ }^{11}$ The domination of global brands (e.g. Coca-Cola, Google, McDonald's) even

\footnotetext{
${ }^{2}$ DURKHEIM, Emile. The division of labour in society. London: Macmillan, 1994; GIDDENS, Anthony. Socjologia; zwiezłe, lecz krytyczne wprowadzenie. Poznań: Zysk i S-ka, 1998.

${ }^{3}$ DOBROWOLSKI, Kazimierz. Teoria podłoża historycznego. In: DOBROWOLSKI, K. Studia z.pogranicza historii i socjologii. Wrocław: Wydawnictwo Polskiej Akademii Nauk, 1967, p. 7.

${ }^{4}$ PRÖSLER, Martin. Museums and globalization. In: MACDONALD, S., FYFE, G. eds. Theorizing museums: representing identity and diversity in a changing world. Cambridge, Mass: Blackwell, 1996, p. 40.

${ }^{5}$ RECTANUS, Mark W. Globalization: incorporating the museum. In: MACDONALD, S. ed. A companion to museum studies, Malden, MA: Blackwell Pub, 2006, p. 382; MURPHY, Bernice. Museums, globalisation and cultural diversity. In: International Journal of Heritage Studies [online]. 1999, year 5, vol. 1, p. 46. DOI: 10.1080/13527259908722246

${ }^{6}$ HUDSON, Kenneth. Social history of museums: what the visitors thought. Palgrave Macmillan, 2014, p. 65; STRÁNSKY, Zbyněk Z. Archeologie a Mužeologie. Brno: Masarykova Univ. v Brně, 2005, p. 155.

${ }^{7}$ PRÖSLER, Museums and globalization..., p. 22.

${ }^{8}$ GIDDENS, Anthony. The consequences of modernity. Stanford, Calif: Stanford Univ. Press, 1997, p. 64.

${ }^{9}$ APPADURAI, Arjun. Modernity at large: cultural dimensions of globalization. Minneapolis, Minn: University of Minnesota Press, 1996, p. 33.

${ }^{10}$ YOUNG, Linda. Globalisation, culture and museums: A review of theory. In: International Journal of Heritage Studies 5 [online], 1999, vol. 1, p. 6. DOI: 10.1080/13527259908722242

${ }^{11}$ WALLERSTEIN, Immanuel. Analiza systemón-swiatów. Warszawa: Wydawnictwo Akademickie Dialog, 2004.
} 
in local markets might illustrate this idea. This is also to be perceived in certain post-communist countries' museums. The introduction of the market-driven economy to the cultural sphere (although this has been criticised) is one such example. Wallerstein's perspective defines Western countries as core states, and post-communist countries, such as Poland and Slovakia, as semi-peripheral. But this is just one point of view. Giddens' definition shows there is a kind of interplay among different actors in the globalisation process. While certain authors agree on the unequal distribution of power among the participants, they also point out the unquestioned agency of peripheral actors. ${ }^{12}$ Exposed to the core states' influence, former communist and third world countries could take different attitudes towards novelties. In the late 1990s, Western patterns were perceived either as an opportunity, or a threat to traditional museum practices. While the symbolic transfers between East and West intensified, there was also some sort of awareness of globalisation as a factor of exploitation..$^{13}$ But globalisation is not only a transfer of patterns. It is also accompanied by the emergence of certain structures which improve this transfer. The development of transnational networks ${ }^{14}$ such as ICOM allows the exchange of symbolic means outside of simple international or interregional cooperation.

While generally acknowledging the usefulness of Wallerstein's framework to our analysis, we reject his idea of a one-directional transfer of patterns. We therefore assume a certain degree of agency among local actors. To include this we would like to introduce Roland Robertson's cultural globalisation theory which underlines the discursive character of the process. He uses the notion of "glocalisation" to describe the process of interaction, selection and merging of patterns produced globally and locally. "Core" patterns are not just forcefully introduced into "peripheral" cultures. They might be applied to a new context only partially. Of course, the introduction of new symbolic systems might develop differently in cultures of strong and weak local identities. ${ }^{15}$ Robertson and Giulianotti proposed four possible strategies for dealing with globalisation in a local context: ${ }^{16}$

- Relativisation-rejection of foreign patterns and concentration on the locality's own, traditional, values;

- Accommodation-pragmatic adaptation of less important foreign symbols and preservation of most important local symbols;

- Hybridisation - a creative combination of local and foreign patterns;

- Transformation - approval of supra-local patterns, creation of new patterns on their basis or-in extreme situations-substitution of local symbols with new ones.

Local actors do not only depend on "global" players, but also on their national-level partners. The rules of their functioning are partially shaped by national law and financed by national government (via local governments). Different relations between national centres and different local resources containing natural, economic and cultural elements create unequal status between regions and localities. This may create central-peripheral dependency within

\footnotetext{
${ }^{12}$ GUPTA, Akhil, FERGUSON, James. Discipline and practice: "the field" as site, method, and location in anthropology. In: GUPTA, A., FERGUSON, J. eds. Anthropological locations; boundaries and grounds of a field science. Berkeley, Los Angeles, London: University of California Press, 1997, p. 35.

${ }^{13}$ BEZZEG, Maria. The influence of globalisation on museology. In: International Journal of Heritage Studies 5 [online], 1999, vol. 1, p. 16. DOI: 10.1080/13527259908722243

${ }^{14}$ CASTELLS, Manuel. The rise of the network society. Chichester: Wiley-Blackwell, 2010.

${ }^{15}$ ROBERTSON, Roland. Globalization: social theory and global culture. London: SAGE, 1992, p. 173.

${ }^{16}$ GIULIANOTTI, Richard, ROBERTSON, Roland. Forms of glocalization: globalization and the migration strategies of Scottish football fans in North America. In: Sociology 41, 2007, vol. 133, p. 135.
} 
nation-states and regions as well. ${ }^{17}$ This leads to the conclusion that some regions might be double-peripheries: peripheral regions of peripheral countries. In Poland and Slovakia, this notion might refer to Subcarpathian voivodeship and parts of the Košice region. They are peripheral in at least two ways: economically and geographically. They are less developed than the rest of their countries and situated at the outer border of the EU. Theoretically, patterns constructed in cores should reach them with a significant delay.

This brings the narrative to a certain conclusion and to the explication of this paper's aim. We would like to analyse the educational practices of certain Polish and Slovak museums in relation to patterns constructed in Western countries in order to determine whether peripheral museums of Central-Eastern Europe are open or closed to ideas of the new museology. We assume that the existence of ICOM and other transnational organisations involved in the sphere of cultural heritage makes it more difficult to precisely designate the core of the museum field. However, they undoubtedly support the construction of models or reference points for core as well as peripheral museums.

\section{Towards an ideal type of museum education}

Research shows a divergence in the understanding of museum education among actors within the field. In some of Polish museums the idea is treated as an umbrella term covering those sorts of museum work which are not collection-oriented (or have anything to do with interaction with museum's milieu) ${ }^{18}$ From the sociological point of view, it would be acceptable to include all uses of this term. This "bottom-up" approach will be applied to the analytical part of the paper. An additional approach needs to be included, however, to provide the definition of museum education which is accepted as referential for the museum field. We argue that the ideal type of museum education is constructed upon concepts developed in the most influential institutions, which then might be compared with the actual functioning of museums in the peripheries.

The notion of ideal type as a methodological tool was introduced by Max Weber more than 100 years ago. It is an analytical construct-non-existent in empirical reality-composed of one or more points of view and emphasising certain aspects of a certain phenomenon. ${ }^{19}$ Based on concepts developed by Western European or American museologists (thus core-state representatives), we will construct an ideal type of museum education. This does not mean that we favour those patterns or treat them as "better", or adhere to postcolonial thinking about museums. Rather, this strategy is a way of finding out whether global or local models of education dominate in semi-peripheries.

Construction of the ideal type would include explication of the desired meaning of museum pedagogy, situating it within the system of all museum practices, listing a set of activities which are "educational", and including participants (educators and audience). A useful tool for ordering and analysing cultural elements is provided by Wendy Griswold. Her "cultural diamond" allows the drawing of relationships between museum education (treated as a cultural

\footnotetext{
${ }^{17}$ BROSZKIEWICZ, Wojciech. Kapitat kulturowy mtodego pokolenia Polski wspótczesnej: studium na prayketadzie wybranych spoteczności Podkarpacia. Rzeszów: Wydawn. Uniwersytetu Rzeszowskiego, 2010, p. 75.

${ }^{18}$ GRZONKOWSKA, Joanna, GÓRKA, Jacek. Edukacja a promocja - wspólne pola działalności. Współpraca czy rywalizacja? In: Muzealnictwo 54, p. 34.

${ }^{19}$ WEBER, Max. "Objectivity” in social science. In: SHILS, E.A., FINCH, H.A. eds. Max Weber on the methodology of the social sciences. Glencoe, Illinois: The Free Press, 1949, p. 90.
} 
object), society, creators and receivers. ${ }^{20}$ Local educators reach for pedagogical ideas developed in core states and popularised via global networks, yet they use them in accordance with local regulations.

\section{Importance}

Education is considered to be an important element of museum functioning. It is included in the informative function of the three-part system provided by Stephen E. Weil (to protect, to study, to inform) treated as the basis of the "new museology". ${ }^{21}$ The movement emphasised the opening of institutions to their milieus and the change in the modern formula of the museum from the place of "enlightenment" to a participative model. At the global level the importance of pedagogy is strengthened by its institutionalisation: the Committee for Education and Cultural Action was one of the first international committees of ICOM, besides national organisations (like the Museum Educators Forum in Poland).

\section{Distinction}

Museum education is connected to the museum's communicative functions. ${ }^{22}$ According to the document "Characteristics and quality criteria for museum education", the practice is composed of three elements: (1) the science of education and communication; (2) museology; (3) the specialisation of the museum. ${ }^{23}$ This definition clearly moves the activity away from marketing practices, which are sometimes treated as a form of education. This leads to the disciplinary distinction: a certain set of activities focused on visitors requiring pedagogical and museological skills. Lucie Jagošová names museum pedagogue as a separate museum profession. ${ }^{24}$ This is more and more often reflected in a formal, organisational distinction-the creation of educational positions or pedagogical departments in museums

\section{A broad choice of methods}

While the traditional experience of a museum visit is connected to an individual exploration or a guided tour, museum education consists of a much broader set of activities. ${ }^{25}$ Beginning with the exhibition design (which may offer a more or less educational approach) and lessons similar to those of schools (yet conducted in a different, museum-based context), institutions also offer lectures, workshops, courses, and excursions. ${ }^{26}$ Alongside these, there come some edutainment practices connected to interactive elements of exhibitions, or cultural animation activities which are more or less related to education. They might take a very simple or a

\footnotetext{
${ }^{20}$ GRISWOLD, Wendy. Socjologia kultury: kultury i społeczeństwa w żieniajacym sie swiecie. Warszawa: Wydawnictwo Naukowe PWN, 2013, p. 15. Museum education as a cultural pattern, a system of symbolic meanings and their conduction, is a cultural object. It is an element of broader museum social world but it is also in a relationship with musealised reality.

${ }^{21}$ WEIL, Stephen E. Rethinking the Museum. In: Museum News 69, 1990, vol. 2.

${ }^{22}$ DOLÁK, Jan. Muzeum a prezentace. Bratislava: Muzeológia a kultúrne dedičstvo, 2015, p. 22; TIŠLIAR, Pavol. The Development of Informal Learning and Museum Pedagogy in Museums. In: European Journal of Contemporary Education 6 [online]. 2017, vol. 3, p. 591, accessed 29 December 2019. DOI: 10.13187/ejced.2017.3.586

${ }^{23}$ STRÁNSKÝ, Zbyněk Z. Museology as a science (A thesis). In: Museologia 15, 1980, vol. 11, p. 37; BIEDERMANN, Bernadette. The theory of museology: museology as it is—defined by two pioneers: Zbyněk Z. Stránský and Friedrich Waidacher. In: Museologica Brunensia [online], 2016, vol. 2, p. 53. DOI: 10.5817/MuB2016-2-6

${ }^{24}$ JAGOŠOVÁ, Lucie. Muzejní pedagog jako (semi) profese. In: Muzeológia a kultúrne dedičstvo, 2015, vol. 2, p. 51-53.

${ }_{25}$ TIŠLIAR, The Development of Informal Learning and Museum Pedagogy in Museums, p. 591.

${ }^{26}$ KAČÍREK, Luboš, TIŠLIAR, Pavol. Múzejné exkurzie vo vyučovaní. In: Museologica Brunensia 2, vol. 3 , p. 11.
} 
Dominik Porczyński, Lenka Vargová: Museum education in semi-peripheries: social, cultural and economic aspects...

complex form (such as a cultural event or a festival) and are conducted in or outside the museum building.

\section{Educator as a mediator}

In museum education, the approach to a visitor is related to developments in the general science of education. It seems that museum educational discourse is dominated by progressivism. This is reflected in the popularity of George Hein's constructivist ${ }^{27}$ and David Kolb's experiential learning ${ }^{28}$ theories. Learning in the museum context moves from a form of teaching that is traditional (didactic, expository), and has a one-directional information flow, towards a participatory and visitor-oriented one. The educator's role is not to give final answers, but rather to provide a space where visitors may interact with objects undisturbed, and look for the answers based on their own knowledge.

\section{Full spectrum of visitors}

While formally preoccupied with the education of the lower and middle classes, some museums maintained the aura of exclusiveness. There is an ongoing discussion about whether museums should serve the majority of people or only those who are well-prepared for the museum experience and may fully profit from it. ${ }^{29}$ In particular, art museums were places where only members of the upper classes - those who were well-educated and wealthyfelt comfortable. ${ }^{30}$ They did not provide clear descriptions for unprepared people. An ideal museum is a learning environment for children of all ages as well as a lifelong learning facility. It has educational programmes prepared for individual visitors, families and organised groups; it is also accessible for people with disabilities.

Those five components of the ideal type of museum education might exist in some museums. It is possible to introduce all of them to any institution, yet in reality several factors (social, economic etc.) may prevent the unit from a full embodiment of the idea.

Combining the constructed ideal type of museum education with the cultural diamond gives a broader view of museum education as a social object (Figure 1).

A museum is the centre of a specific "museum" social world and as such it is a referential point for practices for many individuals. ${ }^{31} \mathrm{It}$ includes forms of communication, symbolisation, universes of discourse, activities, memberships, sites, technologies, and organisations. ${ }^{32}$ Designating cultural elements and practices understood as educational allows us to "extract" museum pedagogy from the complex museum "universe" and identify it as a cultural object. Distinction, therefore, is the basis for differentiating education from other museum practices. Its importance situates it in a certain place in the hierarchy of museum activities. It also relates to a museum's (as an institution) or an individual museum employee's recognition of the rank of pedagogy among other tasks.

\footnotetext{
${ }^{27}$ HEIN, George E. The Constructivist Museum. In: Journal for Education in Museums, 1995, vol. 16; HEIN, George E. Edukacja muzealna. In: SZELĄG, M., SKUTNIK, J. eds. Edukacja muzealna. Antologia ttumaczeń. Poznań: Muzeum Narodowe w Poznaniu, 2010.

${ }^{28}$ MAJEWSKI, P. eds. Muzea i uczenie sie przez cate sycie: podrecznik europejski. Warszawa: Narodowy Instytut Muzealnictwa i Ochrony Zbiorów, Muzeum Pałac w Wilanowie, 2013, p. 31.

${ }^{29}$ CLAIR, Jean. Kryzys muzeón: globalizacja kultury. Gdańsk: Słowo/obraz terytoria, 2009, p. 26.

${ }^{30}$ BOURDIEU, Pierre, DARBEL, Alain. The love of art. European art museums and their public. Cambridge: Polity Press, 1991.

${ }^{31}$ SHIBUTANI, Tamotsu. Reference groups as perspectives. In: American Journal of Sociology 60, 1955, vol. 6.

${ }^{32}$ STRAUSS, Anselm. A social world perspective. In: Studies in Symbolic Interaction 1, 1978.
} 
The educator is given the role of a "creator", as a professional whose responsibilities include the organisation of educational activities. Depending on the museum, the number of educators, as well as their working conditions, may vary. This allows us to assume that the museum itself, with its policy, collections and staff, might be treated as an institutional actor influencing the work of the pedagogue (directly) and visitors (indirectly) who represent another element of the cultural diamond of museum education. The final component of the model includes methods. As predefined patterns of actions, they direct an educator's behaviour, but their actual performance is related to a pedagogue's own ideas and the visitors' needs. The relationship between methods, educator and audience is thus discursive.

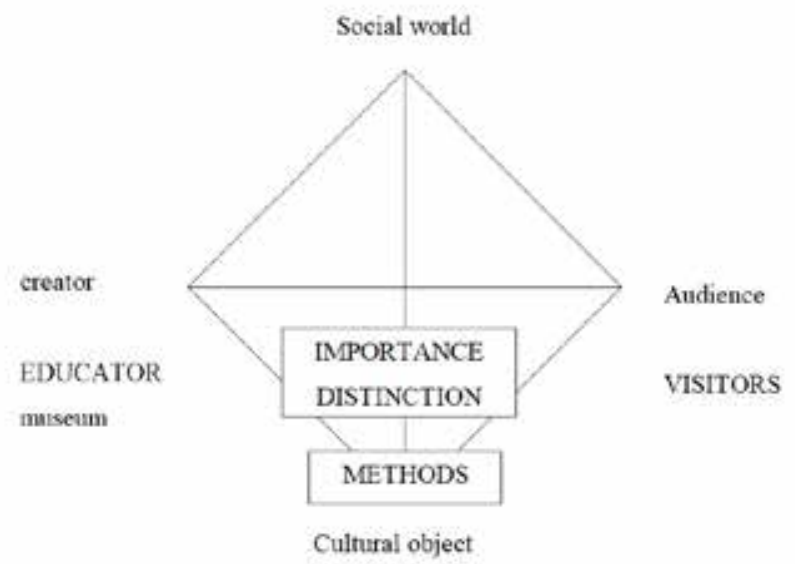

Figure 1: Museum education as a cultural object

\section{Museum education in semi-peripheries}

\subsection{Description of the study}

The data for the purpose of this study was collected in 16 museums. In each of them we conducted one in-depth interview. Our discussants were recruited mostly from the group of museum professionals who are responsible for collection care, research, exhibition planning, etc. (we will call them "curators"). Education might be their secondary duty; however, in many of the investigated museums it is equally as important as the substantial work. In at least three cases, the interlocutors held upper or middle management positions. Our argument is therefore based not on a "pure" educator's perspective, but rather on the perspective of people influencing institutional policies which are in various relations to museum pedagogy. In the research sample we aimed at providing the broadest possible perspective, so in choosing our interlocutors we focused on individuals working both in regional centres and peripheries (museums located in regional capital cities and small, remote locations); ${ }^{33}$ and in large and small museums (from one-person units to those employing dozens of people). However, in every case the institutions were concerned with more than one field of study (art, history, ethnography, archaeology).

Concentrating on finding a peripheral perspective, we chose regions of Poland and Slovakia which might be identified as such. The Subcarpathian voivodeship (województwo podkarpackie) and Košice Region (Košický Kraj) are located in south-eastern parts of Poland and Slovakia respectively, and are thus geographically peripheral regions of the European Union. They are

${ }^{33}$ This gives us the possibility of addressing "double peripheries" or even "triple peripheries". 
economically less well-developed and more excluded compared to the other areas in their respective countries ${ }^{34}$. Election results show also that the Subcarpathian voivodeship is the strongest supporter of the leading conservative and populist party Law and Justice and the right-wing Confederation. ${ }^{35}$ Additionally, the region has a significantly greater percentage of people attending church services when compared to other regions. ${ }^{36}$ The indicators of cultural peripherality of the Košice region are not as significant as the Polish ones. Although the support for populist and conservative parties is greater when compared to Western Slovakia, it is not as high as it is in the central regions of the country. ${ }^{37}$ This may be due to the fact that Košice is the second largest city of Slovakia and its citizens amount to almost one third of the region's inhabitants. Since voters in cities more often choose liberal candidates, this may lead to the balance between regional centre and peripheries when looking at the kraj as a whole. The assessment of the degree of conservatism on the basis of the level of religious practices poses problems since Slovaks are not monoreligious. But based on the percentage of citizens indicating a lack of any religious affiliation, we can say that the Košice region, with $11.3 \%$ of people indicating their non-religiosity, is more religious when compared to western regions of the country. ${ }^{38}$ Again, Košice itself is closer to Bratislava in the topic of non-religiosity.

\subsection{Historical context of museum education in Poland and Slovakia}

The development of museums' educational role in Poland should be connected with the Museum of Industry and Agriculture, founded in Warsaw in 1875. ${ }^{39}$ This kind of institution, rooted in ideas of progress, positivism and industrialisation, was originally dedicated to the provision of agricultural teaching. It promoted research, and organised conferences and seminars. Positivism in Poland, then non-existent as an independent political entity, was dedicated not only to developing science, educating people, and improving living conditions, but also to connecting these purposes with the strengthening of Polish identity and preparing

34 STOPA, Mateusz. New boundaries: regional consciousness in the Polish Subcarpathian Voivodship. In: WOJAKOWSKI, D. ed. Borders and Fields, Cultures and Places: Cases from Poland. Kraków: Nomos, 2008; SZUL, R. Surviving in a peripheral periphery_case studies from eastern Poland. In: EUROPA XXI, 2006, vol. 15, p. 136; KOTARSKI, H., TUZIAK, A., TUZIAK, B. Egzogenne i endogenne czynniki rozwoju regionalnego. Podkarpacie na tle polskich regionów. In: Regionalny wymiar procesón transformacyjnych. Rzeszów: Wydawnictwo Naukowe Uniwersytetu Rzeszowskiego, 2009; NOVOTNÝ, L., MAZUR, M., EGEDY, T. Definition and delimitation of peripheries of Visegrad countries. In: Studia Obszarów Wiejskich 39 [online], 2015, p. 39. DOI: 10.7163/SOW.39.3; MALKOWSKA, A., MALKOWSKI, A. Ocena zróżnicowania rozwoju województw przygranicznych w Polsce Południowej na tle kraju. In: Zessyty Nankowe WSES w Ostrotece 30, 2018, vol. 3, p. 221. Eurostat, At-risk-of-poverty rate by NUTS 2 regions; Eurostat, Severe material deprivation rate by NUTS 2 regions; Eurostat, Gross domestic product (GDP) at current market prices by NUTS 2 regions, accessed 17 November 2019.

${ }^{35}$ Wyniki głosowania_Okreg wyborczy nr 9 [Rzeszów]. https://pe2019.pkw.gov.pl/pe2019/pl/wyniki/okr/9; Wybory do Sejmu i Senatu Rzecsypospolitej Polskiej 2019. https://wybory.gov.pl/sejmsenat2019/pl/wyniki/sejm/okr/23; https:// wybory.gov.pl/sejmsenat2019/pl/wyniki/sejm/okr/22, accessed 25 November 2019.

${ }^{36}$ Additionally, the data shows a significant difference between communicantes and dominicantes in favour of the former. This might be interpreted as participation in a church service as an element of tradition and not as the indicator of actual faith. SADLON Wojciech (ed.), Annuarium Statisticum Ecclesiae in Polonia AD 2019, Warsaw: Instytut Statystyki Kościoła Katolickiego, p. 27-34. Compare with LUCKMANN Thomas, The invisible religion: the problem of religion in modern society. New York: The Macmillan Company, 1967.

${ }^{37}$ Number and share of valid votes cast for political parties by territorial division http://volby.statistics.sk/nrsr/ nrsr2016/en/data02.html, accessed 17 November 2019; Vote share in territorial districts and communes by political parties http://volby.statistics.sk/ep/ep2019/en/data02.html, accessed 17 November 2019.

${ }^{38}$ Resident Population by religion, by regions, 2001, 2011 Census, accessed 29 December 2019.

${ }^{39}$ HUDSON, A social history..., p. 64. 
to fight for independence (so-called "organic work" and "work at the grass roots"). The Museum of Industry and Agriculture provided an environment for learning about Polish history and raising patriotic attitudes. ${ }^{40}$ Similar motives guided organisers of regional museums in Galicia-the Habsburg-occupied part of Poland. The Museum of the Society of Friends of Learning, founded in 1909 in Przemyśl, was deeply involved in educational work with the youth. ${ }^{41}$ Patriotic education was also the basis for cooperation between schools and museums in the late nineteenth and early twentieth centuries. ${ }^{42}$

It is difficult to describe the beginnings of Slovak museum education because of poor access to historic data and literature on the problem. With great caution, we can state that as the whole set of activities was connected to Slovak identity, including the formation of museums and collections, the museum pedagogy of the period was suppressed by the process of Magyarisation. ${ }^{43}$ However, it is possible that its purpose was, to some extent, connected to the problem of maintaining (Slovak) national identity. ${ }^{44}$

The restoration of independence stimulated the popularisation of regional museums; however, fatal economic and political conditions hampered the process. The first formal Polish educational department was founded in 1936 in the National Museum in Warsaw. Thematic guided tours, publishing, operating cinema, and collecting feedback from the audience were among its responsibilities. The unit developed cooperation between the museum and schools, instructing teachers to conduct their own museum classes and to support them in the realisation of curricula. ${ }^{45}$

After the Second World War, Polish and Slovak (or Czechoslovak) culture demonstrated similarities to the Soviet model, at least in the 1950s. Museum communication and display strategies were connected to communist ideology. ${ }^{46}$ In Czechoslovakia, museums were often defined as both "scientific-research" and "cultural-educational" facilities. Through their edifying work, they were supposed to promote socialist patriotism, but also to educate people and help them to understand the context of facts. ${ }^{47}$ In the Polish People's Republic it was suggested that museums might play an important educational role along with schools and family. In the 1960s, the term "museums as universities of culture" was coined. There was also an emphasis on encouraging society to participate in museum enterprises. Educational departments became elements of organisational structures, at least in the largest institutions. Large-scale social research was conducted to provide empirical data for museum teaching practices and the workgroup "Museum pedagogy" was founded as well. ${ }^{48}$ Another important

\footnotetext{
${ }^{40}$ Ibidem.

${ }^{41}$ STOJAK, Grażyna. Świat wychowania przez sztuki piekene w polskiej sžkole: edukacyjne aspekty wychowania przez sz̨tuke w kształceniu nauczycieli plastyki. Kraków: Oficyna Wydawnicza "Impuls", 2007, p. 112.

${ }^{42}$ Ibidem.

${ }^{43}$ DUCREUX, M.-E. Czechy i Węgry w monarchii habsburskiej w XVIII-XIX wieku. In: KŁOCZOWSKI, J., BEAUVOIS, D. eds. Historia Europy Środkowo-Wschodniej. Lublin: Instytut Europy Środkowo-Wschodniej, 2000, p. 389, 396, 402, 408.

${ }^{44}$ KAČÍREK, Luboš. Revolúcia 1848/1849 a Slovenské národné hnutie v múzejnej prezentácii. In: Museologica Brunensia [online], 2019, vol. 1, p. 19. DOI: 10.5817/MuB2019-1-3

${ }^{45}$ SZELĄG, P. Wprowadzenie do historii edukacji muzealnej w Polsce. In: SZELĄG, M. ed. Edukacja muzealna $w$ Polsce. Sytuacja, kontekst, perspektymy rozpoju. Raport o stanie edukacji muzealnej w Polsce. Warszawa: Narodowy Instytut Muzealnictwa i Ochrony Zbiorów, Muzeum Pałac w Wilanowie, 2012.

${ }^{46}$ STRANSKY, Muzeologie a Archelogie...

${ }^{47}$ GREGOROVÁ, Anna. Múzeá a múzejníctvo. Martin: Matica Slovenská, 1984, p. 62, 66, 116.

${ }^{48}$ STOJAK, Świat wychowania przez sztuki piękne..., p. 118-119.
} 
thing was that the position of a museum educator, then called "social-educational worker", was defined in a legal way along, with a list of their responsibilities, which were significantly broad. ${ }^{49}$ The problem of cooperation between museums and schools became the topic of publications written either by academics or museum staff. Problems of linking museum visits with school curricula became the topic of several publications. ${ }^{50}$ While the scope of pedagogical activities was quite broad (depending on the museum), it was mainly based on a traditional didactic and illustrative methodology. The actual status of museum pedagogues, which remained low, was another problem. While the legal basis for the organisation of museum education was promising, social-educational workers were not treated seriously by curators and managers. Pedagogical departments were places where people were assigned work while they waited for a vacant curatorial position. Scholarly work was regarded as more important. The lack of implementation of legal regulations and the employment of people who treated the positions of social educational staff as temporary were often the cause of poor quality in education. ${ }^{51}$

In current Polish museum pedagogy many changes may be observed. Educators have developed their own identity and sense of community. Thanks to increased access to the works of their foreign colleagues, they began to introduce ideas which were successfully implemented in Western countries. Thus - at least in the official discourse-George Hein's constructivist approach became the theoretical basis for museum education. Polish museum educators have their own organisation - the Forum of Museum Educators; they organise conferences and courses, do research and publish, thus demonstrating awareness of the changing social and cultural context.

A similar process may be identified in Slovakia. In 2008, the Union of Museums in Slovakia founded the Commission for Upbringing and Education in Museums, whose goal is to strengthen the position of education in Slovak museums. They organise and promote events for museum professionals in this field, recommend relevant literature, and even aim to create an archive of museum education materials created in Slovak museums. ${ }^{52}$ The Slovak National Museum institutionalised museum education in one of its departments, the Centre for Museum Communication, as well. Some of its tasks are to prepare and carry out educational programmes, or to provide informal education in the field of museum education. ${ }^{53}$ They even offer a course on museum education for employees of museums and other Slovak cultural institutions. ${ }^{54}$

Finally, courses on museum education are offered by Slovak and Polish universities. The Museology and Cultural Heritage study programme (Comenius University, Bratislava, Department of Ethnology and Museology) has courses on museum pedagogy as part of its

\footnotetext{
${ }^{49}$ SZELĄG, Wprowadzenie...

${ }^{50}$ GOLASZEWSKI, Tadeusz. Driecko w muzeum. Funkcje muzeum w wychowaniu estetycznym driecka. Warszawa: Nasza Księgarnia, 1967, p. 31; UNGER, P. Muz̨ea w nauczaniu historii. Warszawa: Wydawnictwa Szkolne i Pedagogiczne, 1988, p. 24; ZIELECKI, A. Podstawy metodyczne wykorzystywania pamiątek przeszłości w nauczaniu historii. In: ZIELECKI, A. ed. Muzeum w nauczaniu historii. Rzeszów: Wydawnictwo Wyższej Szkoły Pedagogicznej w Rzeszowie, 1989, p. 20.

${ }^{51}$ Ibidem.

${ }^{52}$ Odborná komisia pre výchovu a vzdelávanie v múzeách, accessed 23 November 2019, http://okvav.zms.sk/. Fond múzejnopedagogických materiálov, accessed 23 November 2019, http://okvav.zms.sk/ako-vieme-pomoct-my/fond-muzejnopedagogickych-materialov/.

53 Centrum múzejnej komunikácie, accessed 23 November 2019, https://www.snm.sk/?centrum-muzejnejkomunikacie-2.

${ }^{54}$ Kurz. Múrejná pedagogika, accessed 23 November 2019, https://www.snm.sk/?kurz-muzejna-pedagogika.
} 
school curricula. Additionally, a joint study programme-Museology-Pedagogy-is about to be opened. ${ }^{55}$ In Poland, the University of Rzeszów offers a master's degree course preparing future museum educators ${ }^{56}$ and the University of Maria Curie-Skłodowska in Lublin runs a postgraduate study programme on the subject. ${ }^{57}$

To sum up, at least two patterns exist in today's museum education. The first one has its origin in the communist period (or even in the nineteenth century), with a traditional, onedirectional, pedagogy and the educator considered to be of lower status; the second one places equal importance on scholarly work and education, which is sensitive to the changing needs of the audience and the whole society as well.

\subsection{Importance}

The importance of museum education is defined not only in relation to other sorts of museum practices, but also in a broader context. It sets up a system of links between different museum staff positions and the emphasis which is put on different fields of institutional work. As a pedagogical enterprise, it is compared to the overall system of education or upbringing, and it seems to be a universal practice-noticeable in Polish as well as Slovak interviews. It is also described as one of the activities building up the relationship between the institution and local government. In the case of Poland, the interlocutor's professional background and his/her position in the museum influence his/her evaluation of the importance of education. Graduates of studies in which the curricula included developing pedagogical skills ${ }^{58}$ are more positively oriented towards educational activities.

There is a difference between the two countries in the case of curators (who are viewed as scientists or researchers) and educators' mutual recognition. In Slovakia the cooperation between them is emphasised:

[...] Curator should be a scientist, a researcher, in the first place. And then there should be someone who can transform these things and findings into a form suitable for children. So yes, museums definitely have this educational function, but as I said, there are mostly those museum educators for that in museums. [SK-4]

In Poland curators sometimes show their superiority over pedagogues. In the 2016 study, ${ }^{59}$ curatorial work (research and collection building) was shown as the core of one of the museums since the outcomes of this work provide the basis for educational practices. In the case of the interviews we analysed, this perspective is also visible, yet not as sound as in the case of the cited study:

\footnotetext{
${ }^{55}$ Realizované študijné programy muz̨eológie 2.1.24, accessed 23 November 2019, http:/ / muzeologia.sk/studij_programy. htm.

${ }^{56}$ Muzeologia na Uniwersytecie Rzeszowskim. http://www.muzeologia.ur.edu.pl/?page_id=22, accessed 02 February 2019.

${ }^{57}$ Edukacja muzealna. https://www.umcs.pl/pl/wyszukiwarka-studiow,118,edukacja-muzealna,64629.chtm, accessed 29 December 2019.

${ }^{58}$ For example, history studies with teacher specialisation, art education, etc.

${ }^{59}$ PORCZYŃSKI, Dominik. Rosnące znaczenie edukacji. In: PORCZYŃSKI, D., KOSIEK, T. eds. Mužea Podkarpackie 2004-2014: globalizacja i europeizacja a przeobrażenia lokalnych instytucji kultury. Rzeszów: Fundacja Rzeszowska Ośrodka Archeologicznego, 2016, p. 52.
} 
R: Do you watch over the correctness of the educational activities?

I: Yes. Educators always come and show us their ideas of the lessons to check that no errors have crept in. [PL-4]

On the other hand, there are institutions which define education as their only and foremost mission. In the case of amateur museums, education is what drives the functioning of the unit. Exhibitions, guided tours, and museum lessons or workshops completely engage staff and usually include a low number of workers (owner and volunteers). In this case, the practices of collection building and thesaurisation recede into background. If the importance of education was represented on an axis of which one end would represent the lack of importance and the other the primacy of pedagogy among other museum practices, between both these ends several attitudes would appear, including equality of all aspects of museum work.

The importance of museum education was defined earlier in categories of institutionalisation. On a local level it is expressed in the emergence of the formal position of educator as well as independent pedagogy departments. Yet even institutions aware of the need of a specialised educational unit are often limited by their financial capacities. The lack of funding hinders the possibility of employing professional educators, while voluntary docents are still not popular in Poland. This results in the educational practices being conducted by curators in the majority of the Subcarpathian museums. Curators are in fact multi-functional employees. They take care of collections, plan exhibitions, carry out educational programmes, etc. This may result in them focusing on certain duties at the expense of others. In one of the museums, preoccupation with education led to worse collection management and research, while in another, marketing (which is also performed by curators) was the sphere which was evaded due to the lack of time. In fact, there are only a few museums in the Subcarpathian voivodeship which have their own educational units. Their emergence is related to the size of the museum. Usually, the largest ones have their own educational departments, but this does not apply in all cases. For comparison: national museums in Warsaw [PL-6; PL-7] have at least one pedagogical unit focusing on different kinds of teaching and informational practices. As for the Slovak museums studied, most of them have a department of museum pedagogy (or at least a museum educator post), which shows us that this trend is spreading to both bigger and smaller museums.

\subsection{Distinction}

The role of museum education is gaining ever more recognition in museum practice nowadays. It is considered to be a relatively new discipline in Slovak museums, even though not all of its forms are entirely new to them. In fact, one might still come across the opinion that it is a young, not properly defined branch of museum work that is still trying to determine its forms and methods. Also, in Poland there is no universal consensus on the subject of museum education. Some experienced curators-beginning their work in the 1980s-argue that all museum practices are "educational", while others share a conviction that there is a difference between curatorial and pedagogical activities. If - according to the concept developed in the previous chapter-museum teaching draws elements from academic educational preparation, this may be one of the factors distinguishing museum pedagogy from other sorts of museum work. Certainly, interlocutors with pedagogical courses or teaching careers behind them claim that they significantly help in the preparation and conducting of museum educational programmes. 
This relates especially to curators graduating in history with a teaching specialisation. They may use different parts of their education in different fields of their job.

[...] for example I am a teacher by profession and I was never passionate about this occupation. However, I do not deny it is useful because while carrying out educational activities one has a certain support, it is a certain experience gained from the studies and it helps in didactic work. But it's of a completely different character [PL-2].

Another way of distinguishing museum education from other practices is based on a different assessment of musealia importance. While curators focus on, for example, the historical, ethnographical, or artistic (depending on their professional background) qualities of an artefact, educators demonstrate a pragmatic approach. The object is valuable if it might be used in educational practices. An object of low artistic quality, a copy, or a mass-produced product is significant if it helps visitors to understand certain aspects of culture. This is one of the reasons why supporting inventories are created. This does not mean that a more substantive approach is completely rejected. Interlocutors who perform their curatorial or educational responsibilities switch their object-oriented perspectives depending on the situation. In relation to school education, the described activities are pictured as more tangible, allowing a greater degree of involvement and the application of objects which are rarely shown or used during ordinary lessons.

There is an element of market-oriented perspective in developing a well-functioning sphere of museum education. And it appears in both Polish and Slovak institutions. While interlocutors generally agree that the transfer of information about the past to visitors is important, some of them perceive education as the way of providing funds for museum maintenance as well as making the museum noticeable in its local context. While the community-building feature of pedagogy is common for both regions, Polish museum workers speak more openly about the economic aspect of it. Collection building and research is not as visible and attractive for the general audience as visitor-oriented educational practices. A well-run museum with an exquisitely developed educational department might be treated as a valuable resource in territorial marketing strategies as well as a support for actions oriented towards community integration. Since education and marketing are activities which involve dealing with people from outside the institution, they are often treated as almost similar. This often leads to a situation in which museums create departments combining both kinds of responsibilities. This combination may often result in an unjustified merging of education and promotion and treating them as one. In some of the Polish museums, promotional tasks were counted as pedagogical. $^{60}$

Last but not least: setting up independent pedagogical departments in museums (or at least creating individual educational positions), which has been already described as an indicator of the importance of educational practices, is also a means of strengthening the distinction of museum pedagogy from other museum activities. Institutionalisation is a formal way of assigning the responsibilities to individual professionals and supporting the cooperation between various parts of the organisation.

\footnotetext{
${ }^{60}$ SZELĄG, M., GÓRAJEC, P. Edukacja muzealna w Polsce. Podsumowanie "Raportu o stanie edukacji muzealnej w Polsce”. In: SZELĄG, M. ed. Edukacja muzealna w Polsce. Sytuacja, kontekst, perspektywy rozwoju. Raport o stanie edukacji muzealnej $w$ Polsce. Warszawa: Narodowy Instytut Muzealnictwa i Ochrony Zbiorów, Muzeum Pałac w Wilanowie, 2012.
} 


\subsection{Methods}

The common trait for Slovak and Polish museums is the vast range of activities. All of the studied museums offer guided tours of exhibitions, programmes for schools, and museum lessons. Exhibitions are usually designed for individual visits; however, a guide is compulsory in some of the Polish and Slovak institutions. Audio guides are also offered by some units. Electronic devices and multimedia are introduced to cover those aspects of culture which cannot be learned through traditional exhibiting methods. Where musealia, descriptions and charts are not enough, interactive programmes, films and presentations are provided.

Museum lessons are conducted in exhibitions or lecture rooms, though some institutions even have a specifically designated space for these activities. Interviewees seem to understand this kind of pedagogical activity in different ways. Lessons are described as PowerPoint presentations on local history, meetings focused on certain parts of exhibition, and in one case, a guided tour.

The majority of Subcarpathian institutions offer practical activities such as workshops, which are very popular among school groups, especially before Christmas. They may be strongly connected to themes around which exhibitions are built, but in many cases they are not linked to them in any way. However, museums only rarely provide programmes that are very loosely connected to the museum itself, as in the case of the Regional Museum in Dębica, where an IT course was conducted in order to teach some basic computer skills to groups from the University of the Third Age. The link with museum education was established by the inclusion of lessons on how to retrieve archival information. Some of the Polish as well as Slovak units offer day camps for children during holidays.

Excursions also seem to be a standard way of undertaking museum pedagogy in Subcarpathia. They usually focus on places important for local history such as buildings, streets or cemeteries, but one museum also proposes tours in the countryside. Less popular are location-based games utilising local heritage, historical persons, or events. One example is a questing event organised by the District Museum of Rzeszów, "Trail of the Central Industrial District", focusing on the history of the interwar period plan for the development of Polish industry. Additionally, the Košice region's museums offer city tours and special events that take place outside the museum itself.

Some of the museums organise events for larger numbers of people or participate in events prepared by local governments, providing their own booth where activities - which may have varying degrees of educational content-are conducted. They may include historical reenactments, concerts, etc. Educators are also involved in the organisation of commemorative or patriotic events.

Unique practices which were defined as educational include displays of fairy tales with a "retro" slide projector and a beer degustation in a museum preserving local brewery traditions.

In the Podkarpackie voivodeship, most of the described activities are conducted in museum buildings, but some of them are carried out by educators elsewhere: in schools, kindergartens, or community centres. They also help to meet the needs of schools located far from local centres - the towns and cities in which these cultural institutions are located. It is not very common, but some museums include such a possibility in their offer. However, not all are satisfied with the outcomes: 
R: Do you carry out any activities outside? Let's say, visits in schools?

I: We tried, colleagues tried to do this as part of those workshops in nearby villages but it was a little bit of a washout. Sometimes it happened that the school management directed to those lessons many more children than was planned, so it couldn't fully succeed. With such talks or historic lessons we never tried it, however. All of that is related to the lack of personnel. Anyway [...] the IPN ${ }^{61}$ practices [activities outside], but from that what I know museums would rather accept [visitors] in their own locations than go somewhere for such purposes [PL-3].

Insufficient funding is the basic factor which-according to our interlocutors-hampers effective planning and realisation of educational programmes. Underfunding of the cultural sphere also leads to insufficient employment. A low number of staff members can, in some cases, make it very difficult to take care of collections and plan sophisticated pedagogical programmes.

Museums do not concentrate only on museum programmes in their efforts to educate visitors and shape their understanding of the given region. Both permanent and temporary exhibitions also contribute to these goals. After all, it is generally acknowledged that museum exhibitions have a (hidden) educational role. While interlocutors from both countries directly or indirectly imply this, Slovak interlocutors mostly agree that the primary goals of exhibitions are to pass on relevant information, build a positive relationship with the museum, form opinions and attitudes towards the region and its history, or even to raise questions for the visitors to think about on their own. We might say that this shows us that at least some of the museums are using a constructivist approach to learning.

While collections are the basis for museum pedagogy (either exhibited or stored), most of the interlocutors in both regions said that they are trying to use some modern technologies in their exhibitions. There is a slight difference in their motivations, however. Slovak respondents mention that they try to introduce novelties because people expect them to. That is probably one of the reasons why museums nowadays tend to adopt interactive approaches to education and connect the learning process with entertainment (sometimes the term edutainment is used). It is also thought that such an approach makes learning in museums easier and more enjoyable. One of the Polish curators mentioned that multimedia can provide information which for various reasons could not be included in an ordinary exhibition-for example, detailed descriptions or representations of objects which are non-existent or inaccessible. However, traditional elements still prevail because museums mostly do not have sufficient funds for the upkeep of multimedia equipment. Among those that are more common are touch screens, audio guides, or screenings. However, the lack of resources makes it difficult to buy and introduce them.

\subsection{Educational approaches}

While constructivist education is the approach most widely accepted by museum educators, in the Polish museums we studied, a more traditional method dominates. To a greater or lesser extent, educators set themselves in the position of authority on topics related to the museum's profile. It does not mean that individual interpretations made by visitors are not welcomed. The issue depends on two factors, however.

As already mentioned, exhibitions are usually designed for individual visits and equipped with elements supporting visitors in the interpretation process: written descriptions, tour

${ }^{61}$ Institute of National Remembrance. 
guides, audio guides, interactive electronic devices, films, etc. However, one interlocutor admitted that an educator's support is needed to fully learn about the exhibition's topic, and in another museum a guide's assistance is treated as compulsory. This may either mean that the exhibition as a source of information is not able to communicate everything about the local history and culture, or that museums would like to attain control of the interpretation. The educator's assistance is therefore a factor influencing the degree of freedom of interpretation.

The status of the pedagogue and their control of the interpretation is related to the status of the visitor. It is strongly connected to the age of the visitor, their knowledge, their professional background or their ability to support their statements with certain facts:

R: When dealing with visitors, how is the relationship shaped? Do you and the custodian prefer the [kind of] relationship when you speak and guests listen or is the discussion and sharing of thoughts possible?

I: It is possible but after discussing the part [of the exhibition], and not during that. I'm always happy when someone asks questions because it means he/she is interested in something or something interested him/her.

R: Do you allow interpretations different to those you are used to?

I: We may always discuss that.

R: Sometimes somebody considers himself [or herself] an expert and when somebody suggests another interpretation of a certain event, person or object...

I: That's great, but let him [or her] say on what basis, indicate the source [...] [PL-5]

In the case of children and youth, educators situate themselves in the position of authority, assuming that young visitors should be subordinate and listen to the narrative rather than discuss it. It may be caused by at least three factors. Firstly, it is based on a conservative perspective on the relationship between generations. Secondly, educators with an academic pedagogical background based on a traditional "Prussian" model still introduce this to museum teaching. Thirdly, some interlocutors share a conviction that the Polish system of education leaves students unprepared for cultural participation, thus unable to take part in discussion, so museums must provide the knowledge that they lack. In the case of adult visitors, discussion is welcomed since they have the benefit of the previous educational system, and they have greater experience and knowledge, so they are treated as equal disputants. Professionals participating in museum activities as visitors are treated as equal, or, in the case of certain topics, as superior.

Slovak interviewees seem to put more emphasis in their narratives on the overall atmosphere of the museum visit. They point out that it should be pleasant and positive, and that this is especially true for museum education activities. Ideally, museum educators and lectors should be professionals with good communication skills who are able to encourage discussion and tailor the lecture or the programme to the group (children, laymen, professionals):

Of course, we always appeal to our lecturers to ask people whether they have any questions, and to have the knowledge as well [...] to be able to answer them, so that it would not happen that the lecturer cannot answer them or tells them to look it up. [SK-5]

Educators should take on the role of a facilitator to make the museum visit a pleasant experience, so that the visitors will want to come back to the museum. 
Most Slovak interlocutors admitted that some form of museum educational programmes had been in place for a longer time_-even before the political changes in 1989_-just under a different name. Of course, museums (and educational activities) had an additional role at that time-they were supposed to educate people in the official state ideology as well. Nowadays, on the contrary, museums should be politically neutral and try to objectively evaluate the past, even though they can promote feelings of patriotism (in the sense of national or regional identity and pride), belonging, and tolerance. The Polish interviewees did not pay too much attention to the communist period. This is due to the fact that a majority of them did not work in museums before 1989. The participant with the longest experience suggested, however, that the organisation of displays in a local community was based on a balance between formal (i.e. ideological, state) history, and local experiences and memories [PL-1].

\subsection{Visitors}

It is difficult to organise data on museum audiences. The most appropriate classification is based on age and origin. One can venture a statement that the composition of an audience may also say something about the institution. The demographic composition of the museum's social milieu narrows the scope of potential visitors. Elderly people pay a visit to some museums quite often, while in others they rarely show themselves. It is difficult to prepare a programme addressed to university students if there is not any higher educational institution in a town. Thus local demography, a museum's knowledge of it, the educational programmes it offers, and marketing build up the actual audience. Most of the museums studied-regardless of the country - do not focus specifically on one single group of visitors, but they try to cater to the whole population. Of course, the prevalent type of visitors can also be linked to the type of museum, and its exhibitions and programmes. The institutions we studied have developed relationships — often long-term — with different parties, yet some of the interlocutors prefer working with youth and adults, rather than with children. In some cases, they try to form groups of "friends of the museum" or just regular museum-goers through longer-lasting programmes and recurring events.

In the majority of the Polish museums studied, schoolchildren visiting the institutions in organised groups form the most numerous part of the audience. One of the interlocutors stated that they might even amount to $70 \%$ of all the visitors. Cooperation with schools is perceived almost as a basis of educational activities, but not without certain difficulties:

Usually these are weekly activities targeted at organised school groups. Those are, mostly, elementary schools, and these are schools which, as I say, have the opportunity of introducing the topic [of a museum visit] to the plan of implemented curricular activities. Secondary and high schools make the minority [of the organised school groups] [...]. But for this reason we got the signals from teachers there is a problem with the organisation of visits at institutions during the school hours. [...] one hour isn't enough and [in] secondary schools, older elementary school groups, secondary schools and high schools, subjects are taught by different teachers and it is difficult to arrange more time to visit a museum [...] and get back [to school]. [PL-8].

In Slovakia, the idea that museums should serve only as a substitute for schools is outdated. However, that does not mean that museums do not offer programmes or activities for schoolchildren. As in the case of the Subcarpathian voivodeship, elementary and secondary 
schools usually comprise the biggest and probably the most important off-season group of museum visitors. It is only natural that museums try to come up with activities based on school curricula that should complement school subjects, whether they are focused on national history, local history, biology or technical fields. In Slovakia these programmes are always interactive, requiring active cooperation or using forms of play:

R: What would you say was the best way of transferring information to visitors?

I: Well, that would be interactive programmes. That is also for adults. [...] So it is this interactive approach, for example to go over some topic, talk about something, and then to create something for it, like a meeting, or to do something manually, because people like to listen and.... Well, this requires some more work, then, and promotion in public and we have to "educate" the people who come here, because not everyone is interested in it, but there are two appreciative groups, and those are children and the retired. [SK-1]

As already mentioned, in Poland the degree of interactivity is sometimes limited to the questions asked by the educator after his/her presentation. Many museum pedagogues in both regions cooperate with teachers when creating the activities or they even bring those activities over to schools. In this way, museums not only educate children, but try to shape their attitudes towards museums as institutions.

Another large group that museum workers concentrate on comprises elderly, mostly retired, people, because they have a lot of free time and they often welcome the possibility to spend it in an active way. One of the Slovak museums even incorporates a University of the Third Age, while in the case of Polish institutions, Universities of the Third Age are partners and make up an important part of the audience. In both regions some of the studied institutions prepare programmes for pre-school groups. Families with children are an important category of museum visitors as well. Museum workers generally believe that if children see that museums are places where they can both learn new information and have fun, then they will come back more often, and also later on in life. That is why the offered programmes are made to both be informative, and to provide interest and amusement. Museum workers also recognise the need to vary the content of lectures and guided tours based on the age of the audience, thus making them more accessible and easier to understand.

Museums are aware of people with disabilities. As they need special attention and conditions to participate in a museum experience comfortably, some museums have introduced new equipment to help this part of their audience to learn about local history and culture. One of the studied Slovak museums offers specialised programmes for people with impaired vision. A unique feature of certain Košice region museums is also an effort to engage members of national minorities.

The majority of visitors are members of the local community. However, in one case, groups from outside the town form the largest part of the audience. According to the curator, this is due to a lack of support from the local government, which is not interested in historical education and does not encourage teachers to organise museum trips. University students appear only in the narrative of the curator working in Rzeszów. Last but not least, the museums we studied also receive foreign visitors, although they do not form a significant part of the audience in these institutions. Even smaller, local museums attract foreign visitors or visitors 
from different parts of the country during the summer season, thus spreading the awareness of the locality among different groups of people and improving understanding of local traditions.

\section{Conclusions}

In opposition to the simplicity of theoretical framework, the isolation of museum education as a cultural object from the broader context of the museum social world is actually very difficult. In the reality of South-Eastern Poland and Eastern Slovakia, pedagogy seems to be strongly connected and intertwined with other spheres of museum practices such as curatorial and marketing work. This can be seen mostly in the interrelation between the distinction and importance of museum practices. Institutionalisation of educational departments and pedagogical positions is not only a matter of formal differentiation, but also of underlining the significance of pedagogy among all of the museum's responsibilities.

A comparison of museums in the two regions shows certain differences which are mostly grounded in local specifics. Not every region has, for example, a population connected to a strong brewing tradition (as in the Polish town of Leżajsk) or several ethnic minorities (as in the Košice region) that make up a significant part of the audience. However, developing modern exhibitions or educational programmes based on such heritage and including these unique groups in pedagogical strategies shows a certain reflexivity which is actually an indicator of modernisation. $^{62}$

Both regions share a common history, but the interlocutors from each country address the previous political period differently. The organisation of formal culture under communist regimes shaped the specifics of Polish and Slovak (then Czechoslovak) museum pedagogy. While Slovak curators recall in their narratives ideological motives contained in museum work during those times, the Polish speak about certain balance between ideology and wellremembered local history (e.g. commemoration of local members of the Home Army) in the 1980s. There is, however, a certain continuity in museum functioning after the period of "people's democracies". On a social level, this link is provided by curators who trained and worked during the previous political period who also help the younger generation of museum workers to socialise within the organisation. Museum staff with longer work experience are in a position in which they can compare the conditions of the communist period with those of recent times, and identify which of them better support museum work. It also enables them to shape the new generation by transferring both good and bad patterns of conduct.

There are some minor differences between education's importance in Slovakia and Poland. The interviewees from the Košice region describe the relationship between education and curatorial work as an example of functional linking. They depend on each other. The importance of educational practices is also visible in its formalisation: setting up independent pedagogical departments.

The relatively lower rank of museum education in comparison to curatorial responsibilities in Poland shows the continuity between the former and current political periods. It needs to be underlined that the actual situation is not based on ideological, but on social elements. In fact, it is difficult to tell why curators' status is higher than educators'. Maybe longer traditions or being the majority of museum staff were the factors that gave curators stronger positions in Polish museums? Maybe it is that the knowledge of the topic and expertise in research is more

${ }^{62}$ BECK, Ulrich, GIDDENS, Anthony, LASH, Scott. Modernizacja refleksyjna: polityka, tradycja i estetyka w porzadku społecznym nowoczesności. Warszawa: Wydawnictwo Naukowe PWN, 2009, p. 17. 
valued than the actual ability of presenting them to the audience? There is also the economic factor which hampers the improvement of educators' status; however, this did not appear in this research. The lack of proper financial support prevents better organisation of pedagogy units, even if they are considered to be necessary in museum work. ${ }^{63}$

The last difference between the Slovak and Polish museums is a different approach to the educator-visitor interaction. Polish interlocutors seem to be more formal in this aspect. Although they indicate that a more fun-oriented character exists within museum education (in comparison to more formal qualities) a museum visit is strictly connected with transferring the information and its organisation is often reminiscent of a school lesson. It may be compared to Hein's "didactic, expository" education, similar to the schoolteacher-student relationship. It is especially visible in relations with younger visitors. Slovak interlocutors seem to be putting more emphasis on the overall atmosphere of the museum experience and indicating the importance of educator's attitude in this context.

If we do not count the discussed differences, education appears as one of the most important elements of museum work. New methods are developed and introduced to cover all possible members of the audience. The possibilities are limited by money shortages, however.

The fact that museum education in both regions underwent changes is clear. Despite their peripherality, their practices are close to the constructed ideal type. The difference results from local specifics, which is more clearly perceived in Poland. On the basis of the collected data we may state that the globalisation process in the case of museum pedagogy of the Košice and Subcarpathian regions assume the form of hybridisation. Global patterns, such as multiple methods and the broadening of the spectrum of visitors were introduced to everyday practice, yet certain aspects - such as the traditional, school-like pedagogical approach, or considerably lower status of educators in Poland inherited from the former political period-remain unchanged. Looking at the problem from a cultural globalisation perspective, it seems that the process of acquiring global patterns is much more advanced in Slovakia than in Poland. This may also be a result of the lesser degree of conservatism in the region. Still-the differences exist and their interpretation from the cultural perspective only is insufficient. Curators in both countries agree upon the need for introducing changes in museum education, but they find it impossible at the moment due to the lack of proper funding. This shows us that the economic peripherality makes change more difficult. The globalisation of museum education in semiperipheries is then a process of interaction between global patterns and local conservatism along with a constant underfunding of the cultural sphere.

\section{References}

APPADURAI, Arjun (1996). Modernity at large: cultural dimensions of globalization. Minneapolis, Minn: University of Minnesota Press. Public worlds v. 1. ISBN 978-0-8166-2792-9.

BECK, Ulrich, GIDDENS, Anthony, LASH, Scott. Modernizacja refleksyjna: polityka, tradycja $i$ estetyka w porzqdku spotecznym nowoczesności. Warszawa: Wydawnictwo Naukowe PWN, 2009. ISBN 978-83-01-15825-5.

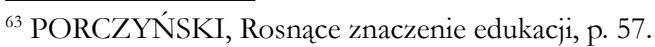


BEZZEG, Maria (1999). The influence of globalisation on museology. In: International Journal of Heritage Studies 5 [online], vol. 1, p. 16-20. ISSN 1352-7258, 1470-3610. DOI: 10.1080/13527259908722243

BIEDERMANN, Bernadette (2016). The theory of museology: museology as it is — defined by two pioneers: Zbyněk Z. Stránský and Friedrich Waidacher. In: Museologica Brunensia [online], vol. 2, p. 51-64. ISSN 1805-4722, 2464-5362. DOI: 10.5817/MuB2016-2-6

BOURDIEU, Pierre, DARBEL, Alain (1991). The love of art. European art museums and their public. Cambridge: Polity Press.

BROSZKIEWICZ, Wojciech (2010). Kapitat kulturowy mtodego pokolenia Polski wspótczesnej: studium na przyktadzie wybranych społeczności Podkarpacia. Wyd. 1. vyd. Rzeszów: Wydawn. Uniwersytetu Rzeszowskiego. ISBN 978-83-7338-568-9.

CASTELLS, Manuel (2010). The rise of the network society. Chichester: Wiley-Blackwell.

CLAIR, Jean (2009). Kryzys muzeów: globalizacja kultury. Gdańsk: Słowo/obraz terytoria.

DOBROWOLSKI, Kazimierz (1967). Teoria podłoża historycznego. In: DOBROWOLSKI, Kazimierz Studia zpogranicza historii $i$ socjologii. Wrocław: Wydawnictwo Polskiej Akademii Nauk, p. 6-51.

DOLÁK, Jan (2015). Muzeum a pręentace. Bratislava: Muzeológia a kultúrne dedičstvo. ISBN 978-80-971715-8-2.

DUCREUX, Marie-Elizabeth (2000). Czechy i Węgry w monarchii habsburskiej w XVIIIXIX wieku. In: KŁOCZOWSKI, Jerzy, BEAUVOIS, Daniel. eds. Historia Europy ŚrodkowoWschodniej. Lublin: Instytut Europy Środkowo-Wschodniej, pp. 318-415. ISBN 978-8385854-52-4.

DURKHEIM, Emile (1994). The division of labour in society. London: Macmillan.

GIDDENS, Anthony (1998). Socjologia; zwiezłe, lecz. krytyczne wprowadzenie. Poznań: Zysk i S-ka.

GIDDENS, Anthony (1997). The consequences of modernity. Stanford, Calif: Stanford Univ. Press. ISBN 978-0-8047-1891-2.

GIULIANOTTI, Richard, ROBERTSON, Roland (2007). Forms of glocalization: globalization and the migration strategies of Scottish football fans in North America. In: Sociology 41, vol. 133, pp. 133-152.

GOLASZEWSKI, Tadeusz (1967). Dįiecko w muzeum. Funk.cje muzeum w wychowaniu estetycznym dziecka. Warszawa: Nasza Księgarnia.

GREGOROVÁ, Anna (1984). Múzeá a múzejníctvo. Martin: Matica Slovenská.

GRISWOLD, Wendy (2013). Socjologia kultury: kultury i spoteczeństwa w żmieniajacym sie swiecie. Warszawa: Wydawnictwo Naukowe PWN. ISBN 978-83-01-17366-1.

GRZONKOWSKA, Joanna, GÓRKA, Jacek . Edukacja a promocja - wspólne pola działalności. Współpraca czy rywalizacja? In: Muzealnictwo, vol. 54, pp. 34-41.

GUPTA, Akhil, FERGUSON, James (1997). Discipline and practice: "the field" as site, method, and location in aAnthropology. In: GUPTA, Akhil, FERGUSON, James. eds. Anthropological locations; boundaries and grounds of a field science. Berkeley, Los Angeles, London: University of California Press, pp. 1-46.

HEIN, George E. (2010). Edukacja muzealna. In: SZELĄG, Marcin, SKUTNIK, Jolanta. eds. Edukacja muzealna. Antologia ttumaczeń. Poznań: Muzeum Narodowe w Poznaniu, pp. 59-81. HEIN, George E. (1995). The Constructivist Museum. In: Journal for Education in Museums, vol. 16, pp. 21-23. 
HUDSON, Kenneth (2014). Social history of museums: what the visitors thought. London: Palgrave Macmillan. ISBN 978-1-349-01759-1.

JAGOŠOVÁ, Lucie (2015). Muzejní pedagog jako (semi) profese. In: Muzeológia a kultúrne dedičstvo 3, vol. 2, pp. 39-58.

KAČÍREK, Luboš (2019). Revolúcia 1848/1849 a Slovenské národné hnutie v múzejnej prezentácii. In: Museologica Brunensia [online], vol. 1, pp. 18-26. ISSN 1805-4722, 2464-5362. DOI: $10.5817 / \mathrm{MuB} 2019-1-3$

KAČÍREK, Luboš, TIŠLIAR, Pavol (2013). Múzejné exkurzie vo vyučovaní. In: Museologica Brunensia 2, vol. 3, pp. 10-15.

KOTARSKI, Hubert, TUZIAK, Arkadiusz, TUZIAK, Bożena (2009). Egzogenne i endogenne czynniki rozwoju regionalnego. Podkarpacie na tle polskich regionów. In: Regionalny wymiar procesón transformacyjnych. Rzeszów: Wydawnictwo Naukowe Uniwersytetu Rzeszowskiego, pp. 107-121.

MAJEWSKI, Piotr. ed. (2013). Muzea i uczenie sie przez cate sycie: podrecznik europejski. Warszawa: Narodowy Instytut Muzealnictwa i Ochrony Zbiorów, Muzeum Pałac w Wilanowie.

MALKOWSKA, Agnieszka, MALKOWSKI, Arkadiusz (2018). Ocena zróżnicowania rozwoju województw przygranicznych w Polsce Południowej na tle kraju. In: Zesayty Nankowe WSES w Ostrotece 30, vol. 3, pp. 206-222. ISSN 2391-9167.

MURPHY, Bernice (1999). Museums, globalisation and cultural diversity. In: International Journal of Heritage Studies 5 [online], vol. 1, pp. 44-51. ISSN 1352-7258, 1470-3610. DOI: 10.1080/13527259908722246

NOVOTNÝ, Ladislav, MAZUR, Marcin, EGEDY, Tamás (2015). Definition and delimitation of peripheries of Visegrad countries. In: Studia Obszarów Wiejskich 39 [online], pp. 35-48. ISSN 16424689. DOI: 10.7163/SOW.39.3

PORCZYŃSKI, Dominik (2016). Rosnące znaczenie edukacji. In: PORCZYŃSKI, Dominik, KOSIEK, Tomasz. eds. Muzea Podkarpackie 2004-2014: globalizacja i europeizacja a przeobrażenia lokalnych instytucji kultury. Rzeszów: Fundacja Rzeszowska Ośrodka Archeologicznego, pp. 50-62. ISBN 978-83-65627-09-4.

PRÖSLER, Martin (1996). Museums and globalization. In: MACDONALD, Sharon, FYFE, Gordon. eds. Theorizing museums: representing identity and diversity in a changing world. Cambridge, Mass: Blackwell, pp. 21-44. Sociological review monograph series. ISBN 978-0-631-201519.

RECTANUS, Mark W. (2006). Globalization: incorporating the museum. In: MACDONALD, Sharon. ed. A companion to museum studies. Malden, MA: Blackwell Pub, pp. 381-397. Blackwell companions in cultural studies 12. ISBN 978-1-4051-0839-3.

ROBERTSON, Roland (1992). Globalization: social theory and global culture. London: SAGE.

SHIBUTANI, Tamotsu (1955). Reference groups as perspectives. In: American Journal of Sociology 60, vol. 6, pp. 562-569.

STOJAK, Grażyna. Świat wychowania przezs stukipiekne w polskiej sqkole: edukacyjne aspekty wychowania przez sz̨uke w ksztatceniu naucaycieli plastyki. Kraków: Oficyna Wydawnicza "Impuls”, 2007. ISBN 978-83-7308-750-7.

STOPA, Mateusz (2008). New boundaries: regional consciousness in the Polish Subcarpathian Voivodship. In: WOJAKOWSKI, Dariusz. ed. Borders and Fields, Cultures and Places: Cases from Poland. Kraków: Nomos, pp. 31-46. 
STRÁNSKY, Zbyněk Z. (2005). Archeologie a Muz̨elogie. Brno: Masarykova Univ. v Brně. ISBN 978-80-210-3861-5.

STRÁNSKÝ, Zbyněk Z. (1980). Museology as a science (A thesis). In: Museologia 15, vol. 11, pp. 33-40.

STRAUSS, Anselm (1978). A social world perspective. In: Studies in Symbolic Interaction 1, pp. 119-128.

SZELA_G, Marcin, GÓRAJEC, Piotr (2012). Edukacja muzealna w Polsce. Podsumowanie "Raportu o stanie edukacji muzealnej w Polsce". In: SZELĄG, Michał. ed. Edukacja muzealna w Polsce. Sytuacja, kontekst, perspektywy rozwoju. Raport o stanie edukacji muzealnej w Polsce. Warszawa: Narodowy Instytut Muzealnictwa i Ochrony Zbiorów, Muzeum Pałac w Wilanowie.

SZELĄG, Paulina (2012). Wprowadzenie do historii edukacji muzealnej w Polsce. In: SZELĄG, Michał. ed. Edukacja muzealna w Polsce. Sytuacja, kontekst, perspektywy rozwoju. Raport o stanie edukacji muzealnej w Polsce. Warszawa: Narodowy Instytut Muzealnictwa i Ochrony Zbiorów, Muzeum Pałac w Wilanowie.

SZUL, Roman (2006). Surviving in a peripheral periphery-case studies from eastern Poland. In: EUROPA XXI., vol. 15, pp. 135-144.

TIŠLIAR, Pavol (2017). The Development of Informal Learning and Museum Pedagogy in Museums. In: European Journal of Contemporary Education 6 [online], vol. 3, accessed 29 December 2019. ISSN 23056746. DOI: $10.13187 /$ ejced.2017.3.586

UNGER, Piotr (1988). Muzea w nauczaniu bistorii. Warszawa: Wydawnictwa Szkolne i Pedagogiczne.

WALLERSTEIN, Immanuel (2004). Analiza systemów-swiatów. Warszawa: Wydawnictwo Akademickie Dialog.

WEBER, Max (1949). "Objectivity" in social science. In: SHILS, Edward A., FINCH, Henry A. eds. Max Weber on the methodology of the social sciences. Glencoe, Illinois: The Free Press.

WEIL, Stephen E. (1990). Rethinking the Museum. In: Museum News 69, vol. 2.

YOUNG, Linda (1999). Globalisation, culture and museums: A review of theory. In: International Journal of Heritage Studies 5 [online], vol. 1, pp. 6-15. ISSN 1352-7258, 1470-3610. DOI: $10.1080 / 13527259908722242$

ZIELECKI, Alojzy (1989). Podstawy metodyczne wykorzystywania pamiątek przeszłości w nauczaniu historii. In: ZIELECKI, Alojzy. ed. Muzeum w nauczaniu historii. Rzeszów: Wydawnictwo Wyższej Szkoły Pedagogicznej w Rzeszowie, pp. 11-38.

\section{Internet sources}

Centrum múrejnej komunikácie, accessed 23 November 2019, https://www.snm.sk/?centrummuzejnej-komunikacie-2.

Edukacja muzealna, accessed 29 December 2019, https://www.umcs.pl/pl/wyszukiwarkastudiow,118,edukacja-muzealna,64629.chtm

Fond múrejno-pedagogických materiálov, accessed 23 November 2019, http://okvav.zms.sk/akovieme-pomoct-my/fond-muzejno-pedagogickych-materialov/.

Kurz Múzejná pedagogika, accessed 23 November 2019, https://www.snm.sk/?kurz-muzejnapedagogika.

Muzeologia na Uniwersytecie Rz̧eszowskim, accessed 02 Februrary 2019, http://www.muzeologia. ur.edu.pl/?page_id=22. 
Dominik Porczyński, Lenka Vargová: Museum education in semi-peripheries: social, cultural and economic aspects...

Number and share of valid votes cast for political parties by territorial division, accessed 17 November 2019, http://volby.statistics.sk/nrsr/nrsr2016/en/data02.html,

Odborná komisia pre výchovu a vadelávanie v múzeách, accessed 23 November 2019, http://okvav. zms.sk/.

Realizované študijné programy muzeológie 2.1.24, accessed 23 November 2019, http:/ / muzeologia. sk/studij_programy.htm.

Resident Population by religion, by regions, 2001, 2011. Census, accessed 29 December 2019.

Vote share in territorial districts and communes by political parties, accessed 17.11.2019, http://volby. statistics.sk/ep/ep2019/en/data02.html.

Wyniki glosowania - Okreg wyborçy nr 9 [Rzeszów], accessed 25 November 2019, https:/ / pe2019. pkw.gov.pl/pe2019/pl/wyniki/okr/9.

Wybory do Sejmu i Senatu Rzeczypospolitej Polskiej 2019, accessed 25 November 2019,

https://wybory.gov.pl/sejmsenat2019/pl/wyniki/sejm/okr/23

https://wybory.gov.pl/sejmsenat2019/pl/wyniki/sejm/okr/22. 